\title{
Dampak Sistem Zonasi bagi Sekolah Menengah Pertama
}

\author{
${ }^{1}$ Dany Miftahul Ula, ${ }^{2}$ Irvan Lestari \\ ${ }^{1,2}$ IKIP Budi Utomo Malang, Indonesia
}

Email: 1danymiftahulula@budiutomomalang.ac.id, 2irvan_ibu@yahoo.com

\section{Tersedia Online di}

http://www.jurnal.unublitar.ac.id/

index.php/briliant

Sejarah Artikel

Diterima pada 23 Oktober 2019

Disetuji pada 15 November 2019

Dipublikasikan pada 29 Februari

2020 Hal. 10-18

\section{Kata Kunci: \\ Dampak; Sistem Zonasi; Sekolah; Masyarakat}

\section{DOI}

http://dx.doi.org/10.28926/briliant. v4i4.375

\begin{abstract}
Abstrak: Tujuan penelitian ini adalah untuk memaparkan fakta di sekolah terkait dampak yang ditimbulkan dari pelaksanaan sistem zonasi tahun 2019 di Kota Malang. Metode penelitian yang digunakan adalah metode kualitatif dengan pendekatan Studi kasus di SMPN 8 Kota Malang. Pengambilan sampel peneliti menggunakan teknik purpossive sampling. Metode pengumpulan data yang digunakan dalam penelitian ini adalah observasi dan deep interview kepada 20 Guru dan 50 Responden dari masyarakat. Hasil temuan penelitian ini meliputi dampak positif dan negatif dari pelaksanaan PPDB sistem zonasi 2019, pertama, dampak positif yang dirasakan oleh Sekolah dan guru sebanyak $21 \%$ saja, dan sisanya $79 \%$ merasakan dampak negatif. Kedua dampak positif yang dirasakan masyarakat hanya mencapai $36 \%$ dan lebih banyak merasakan dampak negatif sebesar 64\%. Dari temuan tersebut mengindikasikan bahwa kebijakan sistem zonasi harus dievaluasi agar kedepannya dapat mengurangi dampak negatif yang ditimbulkan.
\end{abstract}

\section{PENDAHULUAN}

Pendidikan merupakan hak asasi sesuai yang tertera dalam pembukaan UUD 1945 alinea ke-4, mencerdaskan kehidupan bangsa merupakan salah satu tujuan dari para pendiri bangsa. Dalam UUD 1945 pasal 31 mengenai Pendidikan dan Kebudayaan yang sudah keempat kalinya diamandemen, di ayat pertama dinyatakan bahwa setiap warga negara berhak mendapatkan pendidikan Pelaksanaan proses pendidikan ini guna mencerdaskan dan mengembangkan moral bangsa agar menjadi lebih baik dan bermartabat. Dari pasal tersebut mengindikasikan bahwa pendidikan adalah salah satu hal penting sehingga mendorong pemerintah untuk terus meningkatkan kualitas pendidikan.

Selama ini masyarakat telah terbiasa dengan sistem lama yang menjadikan Nilai Ujian Nasional (NUN) sebagai pertimbangan utama bagi siswa untuk melanjutkan ke jenjang sekolah yang lebih tinggi. Hal tersebut dinilai pemerintah menimbulkan terpusatnya siswa dengan nilai tinggi di suatu sekolah dan penumpukan siswa dengan nilai rendah di sekolah lain. Sehingga sekolah hanya memiliki siswa-siswa dengan kemampuan yang seragam. Tanpa disadari, Nilai Ujian Nasional (NUN) juga dapat menjadi penghalang diterimanya calon siswa di sebuah sekolah padahal sekolah tersebut adalah sekolah yang paling dekat dengan tempat tinggal. 
Dapat dipahami jika pemerintah membuat aturan baru dalam sistem PPDB, zonasi sebagai sistem baru yang menghendaki calon siswa diterima bukan lagi karena pertimbangan nilai ujian melainkan karena letak rumah (tempat tinggal) dekat dengan sekolah. Hal ini memungkinkan masyarakat dapat mengakses pendidikan dengan lebih mudah. Sehingga pemerataan pendidikan dalam segala aspek dapat terpenuhi. Kelebihan lain adalah, letak tempat tinggal siswa yang dekat dengan sekolah dapat memangkas biaya transportasi, hal ini tentu dapat meringankan beban orang tua terlebih bagi mereka yang berasal dari kalangan keluarga kurang mampu. Hal ini mengacu pada Permendikbud tahun 14 tahun 2018.

Situmorang (2018) memperkirakan keinginan dari pemerintah dengan kebijakan zonasi yang bertujuan agar terjadi pemerataan pendidikan namun belum tentu mampu menjadikan kualitas sekolah negeri lebih merata, bahkan sekolah negeri pada beberapa tahun ke depan dapat kehilangan kualitasnya dan harus bersaing dengan sekolah swasta yang dinilai masyarakat mampu memberikan fasilitas baik sekalipun berbiaya mahal.

Sistem zonasi merupakan kebijakan yang telah berjalan sejak tahun 2017, yang diharapkan dapat menghilangkan dikotomi sekolah favorit dan non favorit. Perbedaan sistem zonasi tahun ini dengan tahun 2017, sistem zonasi tahun ini diberlakukan ke seluruh sekolah yang diselenggarakan pemerintah daerah. Sedangkan sistem zonasi PPDB 2017 masih tahap adaptasi sehingga dalam praktiknya tidak semua sekolah menerapkan sistem ini. Dan di tahun 2019 semua sekolah yang diselenggarakan pemerintah daerah kecuali SMK wajib menerima peserta didik baru yang tinggal dizona terdekat dengan sekolah minimal 90\% dari total jumlah pesera didik yang diterima. Sisanya $10 \%$ dari total jumlah peserta didik dibagi menjad 2 kriteria, yaiku 5\% untuk jalur prestasi di luar zona terdekat dari sekolah, dan $5 \%$ lagi untuk peserta didik yang mengalami perpindahan domisili atau terjadi bencana (Permendikbud No.14 thn 2018). Selain itu, pemerintah daerah maupun provinsi wajib menerima dan membebaskan biaya pendidikan bagi peserta didik baru yang berasal dari keluarga ekonomi tidak mampu yang berdomisili dalam satu wilayah daerah/provinsi. Jumlah paling sedikit 20\% dari keseluruhan peserta didik yang diterima.

Pemberlakuan kebijakan tersebut banyak menimbulkan protes tidak hanya dialami di kota Malang tempat dilakukannya penelitian ini, namun juga terjadi di beberapa daerah, berikut peneliti sampaikan paparan temuan oleh Dinar Wahyuni dengan judul artikel Pro Kontra Sistem Zonasi Penerimaaan Peserta Didik Baru Tahun Ajaran 2018/2019 dikatakan; "Dalam praktiknya, sistem zonasi PPDB menuai pro kontra di sejumlah daerah. Di Kupang, Nusa Tenggara Timur (NTT) Misalnya, ratusan orang tua murid menggelar aksi unjuk rasa di kantor DPRD NTT dan Dinas Pendidikan NTT, memprotes sistem zonasi PPDB yang menyebabkan anak mereka tidak diterima di sekolah negeri padahal jarak tempat tinggal dengan sekolah negeri sangat dekat. Aksi serupa terjadi di Tangerang, 9 Juli 2018, ratusan orang tua murid menggelar aksi di depan SMP Negeri 23 Tangerang. Aksi semakin panas ketika Kepala Dinas Pendidikan dan Kebudayaan Kota Tangerang, Abduh Surahman hanya memiliki solusi mendaftar ke sekolah swasta terlebih dahulu selama satu tahun, kemudian pindah melalui mekanisme mutasi”. 
Terjadinya beberapa kisruh dan protes di berbagai wilayah tersebut menunjukkan pemerintah belum mampu memenuhi amanat Undang-Undang Sistem Pendidikan Nasional Pasal 11 ayat (1) yang menjamin hak yang sama bagi setiap warga negara untuk mendapatkan pendidikan bermutu. Benarkah nantinya sekolah negeri akan menurun kualitasnya dibandingan dengan kualitas sekolah swasta? Benarkah minat terhadap sekolah swasta akan lebih tinggi dibandingkan masuk ke sekolah negeri? Purnama (2010:29-30) menjelaskan sekolah negeri adalah sekolah yang dibangun dan dikelola oleh pemerintah sedangkan sekolah swasta merupakan sekolah yang didirikan, dibiayai, serta dikelola berdasarkan kebutuhan dan aspirasi masyarakat. Sekolah swasta juga memiliki perbedaan dalam seleksi penerimaan siswa baru yang dipengaruhi oleh kebijakan sekolah negeri dan sekolah swasta tidak terlalu terikat dengan kebijakan pemerintah sebagaimana sekolah Negeri.

Adanya pro dan kontra di masyarakat terkait implementasi sistem zonasi ini menurut pandangan peneliti mengacu pada sebuah teori yakni teori fungsional. Teori ini berusaha melacak penyebab perubahan sosial sampai ketidakpuasan masyarakat akan kondisi sosialnya yang secara pribadi memengaruhi mereka. Teori ini berhasil menjelaskan perubahan sosial yang tingkatnya moderat. Konsep kejutan budaya (cultural lag) dari William F. Ogburn berusaha menjelaskan perubahan sosial dalam kerangka fungsionalis ini, menurutnya meskipun unsurunsur masyarakat saling berhubungan satu sama lain, beberapa unsur lainnya tidak secepat itu, sehingga tertinggal di belakang. Ketinggalan itu menyebabkan terjadinya kesenjangan sosial dan budaya antara unsur-unsur yang berubah sangat cepat dan unsu-unsur yang berubah sangat lambat. Kesenjangan itu akan menyebabkan adanya kejutan dan budaya pada masyarakat. (Ritzer, 2012:403).

Oleh karena itu penelitian ini dibuat bertujuan untuk memaparkan fakta di sekolah dan masyarakat terkait dampak yang ditimbulkan dari pelaksanaan sistem zonasi terutama pelaksanaan di tahun 2019. Fokus penelitiannya adalah menganalisis seberapa besar dampak yang ditimbulkan dari kebijakan sistem zonasi yang diterapkan di tahun 2019 ini. Dengan demikian diharapkan penelitian ini dapat menjadi salah satu rujukan dalam mengembangkan penelitian serupa, serta dapat menjadi salah satu pertimbangan pemerintah dalam mengevaluasi sistem zonasi di masa yang akan datang.

\section{METODE}

Metode penelitian yang digunakan adalah metode kualitatif dengan pendekatan Studi kasus. Adapun yang menjadi objek penelitian adalah beberapa guru SMPN 8 kota Malang dan masyarakat kota Malang yang kebanyakan berprofesi sebagai karyawan Swasta dengan rentang usia 35-55 tahun. Teknik pengambilan sampel yang digunakan dalam penelitian ini yaitu purposive sampling dimana peneliti menentukan obyek penelitian berdasarkan tujuan penelitian. Dari teknik tersebut sampel yang terpilih 20 Guru dan 50 responden masyarakat yang tanggapannya beragam terkait permasalahan sistem zonasi.

Teknik pengumpulan data yang digunakan penulis yakni menggunakan deep interview. Adapun teknik lain yang digunakan dalam pengumpulan data penelitian ini adalah observasi, dokumentasi. Dan dalam penelitian ini menempuh beberapa tahapan sebagai berikut: (1) Identifikasi dan Perumusan Masalah (2) Menentukan Tujuan Penelitian (3) Pengumpulan data menggunakan metode deep 
interview dengan indikator: informan terbuka dan bersedia meluangkan waktu untuk diwawancarai, selain wawancara peneliti juga mengumpulkan reponden dari masyarakat untuk melakukan Focus Group Discussion (FGD) dengan tujuan membahas pro dan kontra terkait kebijakan sistem zonasi (4) Pengolahan Data \& Analisis Data menggunakan model Miles dan Hubermen yang memiliki 3 (tiga) tahap yakni: Reduksi data kemudian penyajian data sehingga menghasilkan penafsiran/verifikasi. (5) Triangulasi Data menggunakan triangulasi sumber dimana pengecekan kebenaran informasi kepada para subjek dan informan penelitian yang telah ditulis oleh peneliti dalam laporan penelitian (6) dan yang terakhir membuat kesimpulan.

\section{HASIL}

Hasil penelitian berjudul "Dampak Sistem Zonasi bagi Sekolah Menengah Pertama (Studi Kasus Pada SMPN 8 Kota Malang)" ini didasarkan pada tujuan dan data yang diperoleh peneliti di lapangan. Perlu dipahami kembali bahwa dampak adalah akibat, imbas, atau pengaruh yang terjadi (baik positif maupun negatif) dari sebuah tindakan yang dilakukan oleh satu atau kelompok orang yang melakukan kegiatan tertentu. Jadi yang menjadi fokus acuan hasil penelitian ini adalah dampak yang ditimbulkan dari adanya kebijakan sistem zonasi di tahun 2019, baik dampak yang bersifat positif maupun dampak yang bersifat negatif terhadap sekolah dan masyarakat. Dan setelah dilakukan penggalian data melalui deep interview dapat ditemukan beberapa hasil seperti berikut:

\section{A. Dampak bagi Sekolah dan Guru}

Implementasi sistem zonasi ini juga berdampak bagi para guru di sekolah, dampak positifnya yakni (1) lebih banyak siswa yang aktif di praktik daripada teori (dianggap menguntungkan bagi guru-guru tertentu); (2) Sebagian guru mengambil hikmah positif dari adanya kebijakan zonasi ini menyatakan bahwa, dengan semakin banyaknya siswa yang sulit memahami dan sulit menyerap materi ini, mengharuskan seorang guru untuk dapat menciptakan metode pembelajaran baru dengan harapan dapat meningkatkan nilai siswa dibawah KKM (3) lebih banyak siswa yang semangat dan termotivasi pada kegiatan outdoor saja (sekali lagi, hanya dianggap menguntungkan bagi sebagian guru/ Mata pelajaran tertentu).

Dampak negatif bagi sekolah dan guru akibat implementasi sistem zonasi antara lain yaitu; (1) sebagian guru mengeluh siswa banyak memperoleh nilai di bawah KKM (terutama mata pelajaran yang terlalu banyak teori); (2) semakin banyak pula terjadi pelanggaran tata tertib seperti membolos, terlambat, berkelahi, tidak mengenakan atribut lengkap dll; (3) dirasa lebih sulit untuk dibimbing; (4) memunculkan pelanggaran-pelanggaran baru yang belum pernah terjadi di tahuntahun sebelumnya; (5) daya juang siswa rendah sehingga banyak siswa zonasi yang meremehkan guru misalnya menunda-nunda tugas yang diberikan; (6) kurang memiliki sopan santun terhadap guru; (7) guru merasa kesulitan mengondisikan kelas terutama guru yang sudah sepuh. (8) terbentuknya genggeng negatif, warisan dari sekolah pada jenjang pendidikan sebelumnya; (9) terjadi banyak perkelahian di luar sekolah karena sudah paham seluk beluk lingkungan; (10) kebiasaan kurang baik di rumah di bawa ke sekolah; (11) pihak sekolah hampir setiap hari mendapat laporan tentang pelanggaran siswa; (12) 
pengawasan orang tua beum efektif meskipun jarak sekoah dekat; (13) prestasi sekolah menurun. Paparan di atas adalah dampak negatif sistem zonasi yang dirasakan oleh guru dan sekolah.

\section{B. Dampak bagi Masyarakat}

Dampak positif yang dirasakan masyarakat dari diberlakukannya sistem zonasi adalah (1) semakin berkurang kemacetan yang ditimbulkan di lingkungan sekolah, meskipun tidak signifikan; (2) peserta didik bertempat tinggal dekat dengan sekolah sehingga dapat memangkas biaya transportasi siswa; (3) persyaratannya sangat mudah jika ingin menyekolahkan anaknya melalui jalur zonasi; (4) keluarga kurang mampu bisa menyekolahkan anaknya disekolah favorit secara gratis (5) ada kebanggaan tersendiri bagi orangtua yang berhasil menyekolahkan putra-putrinya di sekolah favorit yang diinginkan.

Di sisi lain, dampak negatif sistem zonasi yang dirasakan masyarakat diantaranya: (1) dirasa kurang adil bagi siswa yang memiliki prestasi karena akan lebih sulit dapat masuk di sekolah yang dicita-citakan; (2) daya juang siswa menurun karena untuk masuk sekolah favorit tidak perlu nilai bagus; (3) harga rumah disekitar sekolah menjadi jauh lebih mahal, dan banyak orang memburu rumah dekat dengan sekolah favorit; (4) adanya manipulasi tempat tinggal oleh oknum wali siswa agar anaknya dapat sekolah di sekolah favorit; (5) belum di imbangi dengan pemerataan jumlah sekolah negeri dan fasilitas pendidikan yang memadai sehingga memunculkan blank spot di beberapa wilayah kecamatan, (6) konsep sekolah favorit dan non favorit tidak hilang dari pandangan masyarakat terbukti banyak kasus perubahan dan manipulasi KK (kartu Keluarga) (7) konsep penerapan sistem zonasi yang kurang jelas, sehingga ada beberapa wali murid yang mengeluhkan jarak ke sekolah masih jauh meskipun melaui jalur zonasi padahal ada sekolah yang lebih dekat; (8) Dirasa menghilangkan hak anak untuk memilih sekolah yang di inginkan terbukti dari adanya laporan beberapa wali murid ke KPAI (Komisi Perlindungan Anak Indonesia).

\section{PEMBAHASAN}

Jika dikaitkan dengan teori fungsional yang di cetuskan oleh William Ogburn, masalah sistem zonasi ini sama halnya dengan masalah penggunaan alat kontrasepsi pada masa lalu, awalnya kebijakan tersebut banyak ditentang oleh mayoritas masyarakat, penentangan penggunaan alat kontrasepsi muncul karena anggapan di larang oleh agama dan tidak pantas secara kehidupan sosial. Akan tetapi lambat laun dengan kesadaran masyarakat bahwa jumlah penduduk harus dikendalikan akhirnya masyarakat menyadari pentingnya penggunaan alat ini, keadaan ini secara utuh dikaji dalam teori fungsional bahwa kesadaran masyarakat akan terbentuk dengan adanya paradigma atas pengetahuan baru yang didapatkanya.

Pun dengan sistem zonasi awal mula dilaksanakan, kebijakan ini banyak menimbulkan pro dan kontra. Akan tetapi lambat laun jika pemerintah mengkaji secara mendalam teknis pelaksanaan sistem zonasi sebelum diterapakan sepenuhnya, tentunya akan berbeda hasilnya. Seharusnya pemerintah dalam hal ini kementrian pendidikan mampu mengevaluasi apa saja yang menjadi kekurangan dari sistem yang sudah berjalan selama kurang lebih 3 tahun ini. Mengingat banyak pakar sosial menilai jika kebijakan ini cenderung dipaksakan dan banyak bermuatan politik. 
Dampak sistem zonasi bagi sekolah dan guru lebih banyak ditemukan di segi negatifnya. Hal tersebut terlihat dari perbandingan yang ditemukan pada diagram berikut;

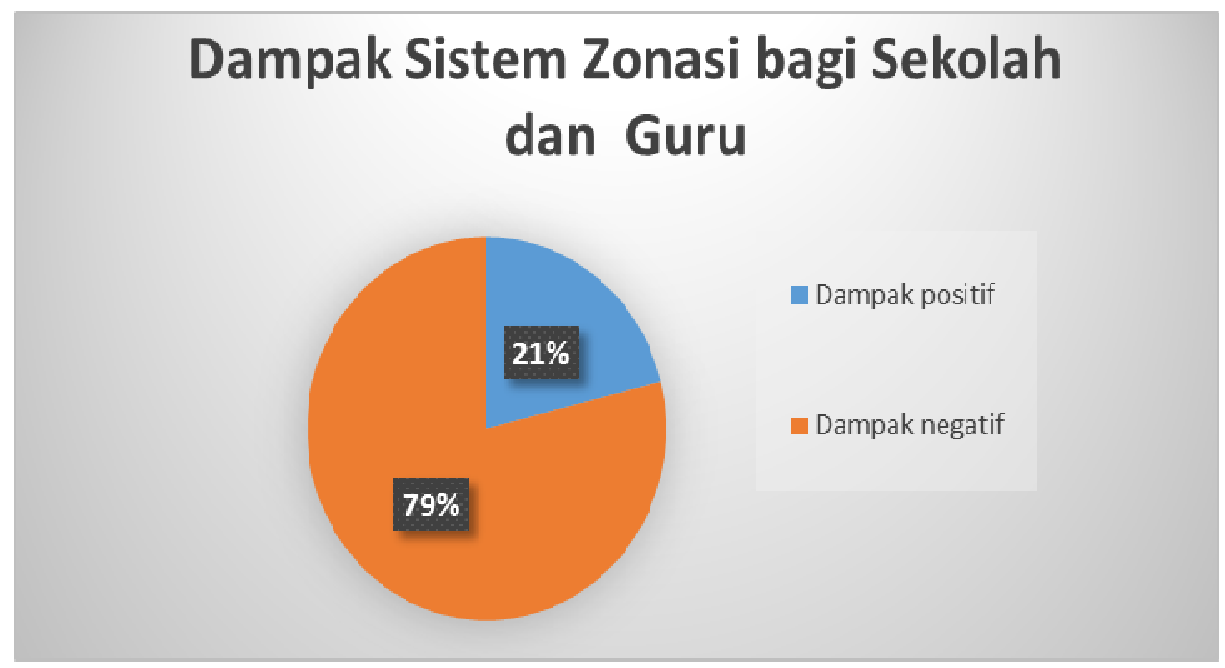

Gambar 1. Dampak sistem zonasi bagi Sekolah dan Guru

Dari hasil diagram tersebut dapat dilihat dampak negatif yang dirasakan sekolah dan guru sebanyak $79 \%$ sedangakan dampak positifnya hanya sebesar 21 $\%$ saja. Begitu juga dari hasil temuan dampak yang dirasakan masyarakat dari pelaksanaan kebijakan sistem zonasi ini bisa dilihat pada diagram dibawah ini;

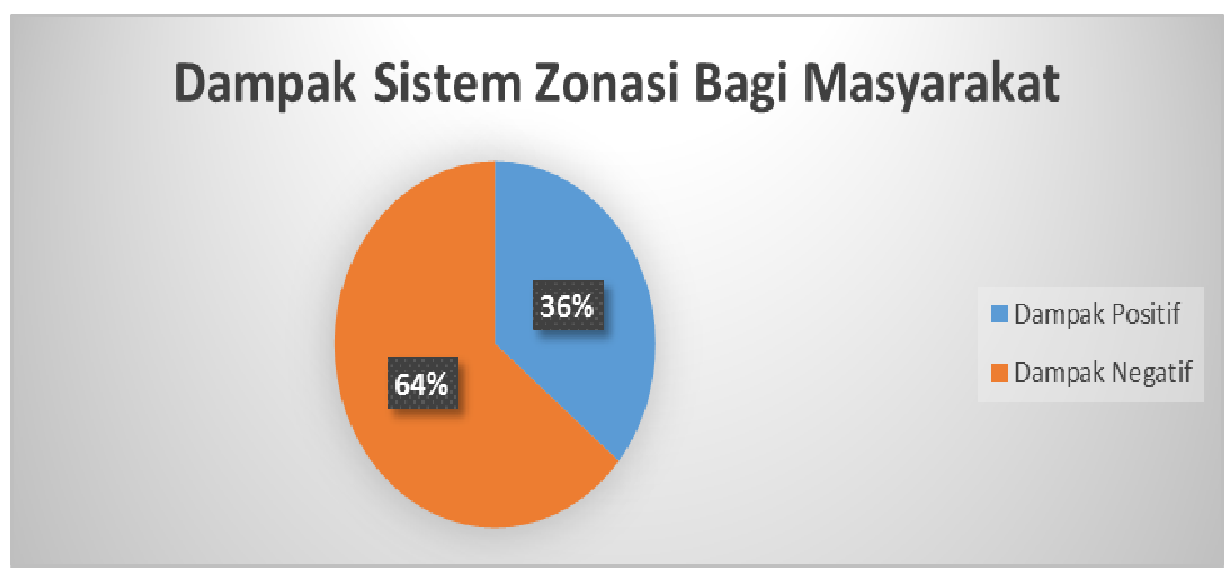

Gambar 2. Dampak sistem zonasi bagi Masyarakat

Pada diagram tersebut dapat dilihat dampak negatif yang dirasakan masyarakat sebanyak 64\% dan sisanya sekitar 36\% mengaggap sistem zonasi memiliki dampak positif. Berdasarkan hasil penelitian ini ditarik kesimpulan bahwa lebih banyak dampak negatif dari pelaksanaan sistem zonasi tahun 2019 ini, jika dibandingkan dengan dampak positifnya. Bukan berarti hal tersebut akan berubah dan berbanding terbalik pada beberapa tahun kedepan, namun jika tidak ada evaluasi dan perubahan dari kebijakan sistem zonasi ini besar kemungkinan semakin banyak dampak negatif yang ditimbulkan dan besar kemungkinan sekolah swasta akan lebih laku dibandingkan sekolah negeri. 
Sebagai pembanding, peneliti akan memparkan hasil temuan yang dilakukan oleh program RISE (Research on Improving Systems of Education) yang telah meneliti 46 sekolah sekolah menengah pertama (SMP) yang ada di Yogyakarta, temuan awal program tersebut menunjukkan bahwa $86 \%$ guru menyatakan sistem zonasi memiliki dampak negatif karena komposisi siswa yang diterima melalui sistem zonasi memiliki nilai rendah yang lebih beragam dibandingkan dengan siswa yang diterima melalui sistem prestasi.

Keadaan ini menuntut guru-guru di sekolah negeri untuk beradaptasi dengan cepat. Para guru yang terbiasa mengajar siswa dengan kemampuan ratarata tinggi, kini harus mengajar siswa dengan nilai rata-rata rendah dengan kemampuan yang sangat beragam. Padahal, keterampilan yang dibutuhkan oleh guru yang mengajar anak-anak berkemampuan tinggi dan berkemampuan rendah berbeda. Anak-anak berkemampuan tinggi membutuhkan tantangan baru dan pengayaan dari guru agar bisa termotivasi dan meningkatkan kemampuannya.

Di sisi lain, anak-anak berkemampuan rendah membutuhkan bantuan guru untuk membangun pemahaman ilmunya dengan benar. Terlebih lagi, tantangan guru dalam mengajar anak dengan kemampuan beragam lebih berat daripada anak dengan kemampuan yang relatif homogen. Guru yang mengajar kelas yang homogen cenderung dapat mengajarkan seluruh siswa dengan seiring sejalan. Namun, ketika kelas yang diajar relatif heterogen, guru harus menyesuaikan pola mengajar untuk mengakomodasi anak yang cepat dan lambat dalam belajar. Semakin besar kesenjangan kemampuan anak, semakin besar beban guru dalam mengajar.

Masalahnya, penyesuaian kemampuan guru mengajar ini tidak bisa dilakukan dalam waktu singkat. Alhasil, proses pembelajaran di kelas tidak bisa berjalan secara optimal dan dapat mengganggu proses belajar di kelas. (theconversation.com)

Dari temuan tersebut dapat disimpulkan bahwa Guru yang akan merasakan dampak langsung dari adanya sistem zonasi sehingga beban berat yang dipikul seorang guru ini tidak akan terbantu jika pemerintah dalam hal ini kementrian pendidikan tidak mengevaluasi kebijakan ini. Namun peneliti dapat menyarankan tiga solusi yang bisa dilakukan sebagai bahan evaluasi Kemendikbud; Pertama, sebelum menerbitkan kebijakan, pemerintah perlu persiapan matang. Penerapan persentase $90 \%$ yang berasal dari jalur wilayah dirasa terlalu besar, harusnya cukup 50\% mengingat belum meratanya kualitas pendidikan. Sistem zonasi bukan hanya tentang jarak, namun lebih jauh lagi untuk mewujudkan pemerataan kualitas pendidikan di Indonesia.

Kedua, perbaiki kualitas dan mutu pendidikan di sekolah, baik sekolah Swasta maupun Negeri jika setiap sekolah telah memperbaiki mutu dan kualitasnya maka semua sekolah akan dianggap favorit dan semakin banyak pilihan sekolah yang bisa jadi alternatif bagi siswa seandainya tidak diterima di satu sekolah dengan alasan zonasi.

Ketiga, menyediakan ketersediaan sekolah negeri di setiap zona, saat ini jumlah sekolah negeri antara satu wilayah dengan wilayah lain tidak merata, ada satu zona/wilayah yang banyak sekolah negerinya sedangkan zona lain tidak, maka dari itu pemerintah harus mengevaluasi proyeksi lulusan sekolah baik negeri maupun swasta agar dapat dijadikan rujukan sebagai ketersediaan sekolah yang akan digunakan untuk menentukan wilayah zonasi. Apabila ditemukan jumlah 
lulusan sekolah lebih sedikit dibandingkan ketersediaan penerimaan maka sebaiknya dilakukan perluasan wilayah zonasi, dengan melakukan cara ini masalah blank spot akan teratasi.

\section{KESIMPULAN}

Berdasarkan uraian hasil temuan tersebut dapat disimpulkan bahwa dampak kebijakan sistem zonasi bagi sekolah dan Masyarakat meliputi dampak positif dan negatif. Dampak negatif bagi sekolah lebih banyak sebesar 79\% dibandingkan dampak positifnya yang hanya $21 \%$. Dampak negatif tersebut diantaranya; (1) siswa banyak memperoleh nilai di bawah KKM, (2) semakin banyak pula terjadi pelanggaran tata tertib, (3) dirasa lebih sulit untuk dibimbing, (4) memunculkan pelanggaran-pelanggaran baru yang belum pernah terjadi di tahun-tahun sebelumnya, (5) daya juang siswa rendah, (6) kurang memiliki sopan santun terhadap guru, (7) guru merasa kesulitan mengondisikan kelas terutama guru yang sudah sepuh, dll. Dan dampak positif yang dirasakan sekolah dan guru diantaranya yakni: (1) lebih banyak siswa yang aktif di praktik daripada teori (dianggap menguntungkan bagi guru-guru tertentu); (2) dengan semakin komplek dan uniknya siswa dari jalur zonasi, guru dinilai mampu menciptakan strategi pembelajaran baru yang harapannya dapat meningkatkan nilai siswa dibawah KKM; (3) lebih banyak siswa yang semangat dan termotivasi pada kegiatan outdoor.

Di sisi lain dampak positif sistem zonasi yang dirasakan masyarakat sebanyak 36\%. Hal tersebut meliputi: (1) semakin berkurang kemacetan yang ditimbulkan di lingkungan sekolah (meskipun tidak signifikan), (2) peserta didik bertempat tinggal dekat dengan sekolah sehingga dapat memangkas biaya transportasi, (3) Persyaratannya sangat mudah jika ingin menyekolahkan anaknya melalui jalur zonasi, (4) keluarga kurang mampu bisa menyekolahkan anaknya disekolah favorit secara gratis. Akan tetapi sebanyak $64 \%$ responden dari masyarakat mengaggap sistem zonasi memiliki dampak negatif antara lain: (1) dirasa kurang adil bagi siswa yang memiliki prestasi karena akan lebih sulit dapat masuk di sekolah yang dicita-citakan; (2) daya juang siswa menurun karena untuk masuk sekolah favorit tidak perlu nilai bagus; (3) harga rumah disekitar sekolah menjadi lebih mahal, dan banyak orang memburu rumah dekat dengan sekolah favorit; (4) adanya manipulasi tempat tinggal oleh oknum wali siswa agar anaknya dapat sekolah di sekolah favorit; (5) belum diimbangi dengan pemerataan jumlah sekolah negeri dan fasilitas pendidikan yang memadai sehingga memunculkan blank spot di beberapa wilayah kecamatan, dll.

Dari hasil temuan tersebut, peneliti masih ingin melakukan penelitian lanjutan yang tetap berkaitan dengan sisitem zonasi, yakni tentang bagaimana strategi sekolah meningkatan mutu dan kualitas pendidikan sebagai dampak negatif dari adanya sistem zonasi, mengingat ada beberapa sekolah yang sanggup mempertahankan kredibilitasnya sebagai sekolah favorit dan tetap mencetak siswa berprestasi meskipun sudah menerapkan sistem zonasi.

\section{SARAN}

Pertama, Sebelum menerbitkan kebijakan, pemerintah perlu persiapan matang, karena penerapan $90 \%$ jalur wilayah dinilai terlau besar dan belum diimbangi dengan pemerataan kualitas pendidikan. Kedua, Sebelum menerapkan 
sistem zonasi 100\% sebaiknya pemerintah memperbaiki mutu dan kualitas pendidikan (sekolah) sehingga dengan sendirinya masyarakat tidak akan berebut sekolah favorit karena semua sekolah dianggap favorit. Ketiga, Meratakan ketersediaan jumlah sekolah negeri sebanding dengan jumlah lulusan di suatu wilayah untuk mengatasi blank spot.

\section{DAFTAR RUJUKAN}

Abdullah Idi, Haji. (2014). Sosiologi Pendidikan (Individu, Masyarakat dan Pendidikan). Jakarta: Rajawali Pers

Ali, Muhhamad. (2017). Kebijakan PendidikanMennegahdalam Perspektif Governance di Indonesia. Malang: UB Press..

Detik News, (2018). "Ramai Soal PPDB, Begini Aturan Sistem Zonasi Sekolah", https://news.detik.com/berita/d-4097504/ramai-soal-ppdb-begini-aturansistem-sistem-sekoah., Diakses pada 28 Mei 2019.

Damsar, Prof. (2015). Pengantar Sosiologi Pendidikan. Jakarta: Prenada Media Group

Kompas, (2018). "Ini Aturan Mengenai Sistem Zonasi", http://edukasi.kompas.com/read/2018/06/05/16092291/ini-aturan-mengenaisistem-zonasi. , Diakses pada 2 Juni 2019.

Moloeng, Lexy J. (2005). Metodologi Penelilian Kualitaif, Bandung: PT. Remaja Rosda Karya

Purnama, Dian. (2010). Cermat Memilih Sekolah Menengah. Jakarta: Gagas Media.

Raco, J.R. (2010) Metode Penelitian Kualitatif: Jenis, Karateristik, dan Keunggulannya. Jakarta: Grasindo

Ristekdikti, (2016). "Undang-Undang Republik Indonesia Nomor 20 Tahun 2003 Tentang Sistem Pendidikan Nasional” (online). (Kelebagaan.ristekdikti.go.id/wp-

content/uploads/2016/08/UU_no_20_th_2003.pdf), diakses pada 29 Juli 2018.

Ritzer, George. (2007). Teori Sosiologi Modern. Yogyakarta: Kreasi Wacana

Situmorang, Riduan, (2018) "Memperbaiki Sistem Zonasi" Koran Jakarta,. (Online). (http://www.koran-jakarta.com/memperbaiki-sistem -zonasi/) diakses pada tanggal 13 Januari 2019

Sopianto, (2015) 'Implementasi Kebijakan Penerimaan Peserta Didik Baru (Ppdb) Online Tngkat Sekolah Menengah Atas Di Kota Pekanbaru Tahun20112013. Jom FISIP Volume2No.1-February. (Online) (http://jom.unri.ac.id/index.php/ JOMFISIP/article/view/5052/4933.) diakses pada 11 Mei 2019

The Conversation, (2019). "Dampak sistem zonasi penerimaan peserta didik baru di sekolah negeri bagi para guru dan siswa", https://theconversation.com/dampak-sistem-zonasi-penerimaan-pesertadidik-baru-di-sekolah-negeri-bagi-para-guru-dan-siswa-119294 , diakses pada 11 November 2019

Wahyuni, Dinar. (2018) "Pro Kontra Sistem Zonasi Penerimaan Peserta Didik Baru Tahun Ajaran 2018/2019" Info Singkat Bidang kesejahteraan Sosial Vol.X,No.14/II/Puslit/Juli/2018. (online) (http://puslit.dpr.go.id) diakses pada 2 Mei 2019. 